Potravinarstvo Slovak Journal of Food Sciences vol. 13, 2019, no. 1, p. 1034-1039

https://doi.org/10.5219/1216

Received: 12 October 2019. Accepted: 17 December 2019. Available online: 28 December 2019 at www.potravinarstvo.com

(C) 2019 Potravinarstvo Slovak Journal of Food Sciences, License: CC BY 3.0

ISSN 1337-0960 (online)

\title{
THE IMPACT OF INAPPROPRIATE FOOD ADVERTISING ON CONSUMER BEHAVIOR
}

\author{
Zdenka Kádeková, Ingrida Košičiarová, Mária Holotová, Lubica Kubicová, Kristína Predanocyová
}

\begin{abstract}
The impact of food advertising on consumer behavior is a matter of concern to psychologists, marketers, economists and the general public alike. It is well known that the consumer is not rational, and all the time does not carefully evaluate all available alternatives before purchase. There exist many stimuli influencing consumer behavior, which refers to the study of buying tendencies of consumers. There are several stages a consumer goes through before he finally picks up products available in the market. Various factors, be it cultural, social, personal or psychological, influence the buying decision of individuals. Submitted paper deals with the impact of inappropriate advertising on consumer behavior, namely the purchase of food. Related research was conducted at Department of Marketing and Trade, FEM SUA in Nitra, based on a questionnaire survey with a sample of 702 respondents from the Slovak Republic. We have used two research methods: Chi Square contingency test and Kolmogorov - Smirnov test. Obtained results proved that $38 \%$ of respondents have a personal experience with inappropriate food advertising and most respondents considered inappropriate food advertising as a deceptive, misleading and manipulative one. It was confirmed that the perception of inappropriate food advertising is not dependent on the age of the respondents and respondents do not avoid buying food previously seen in inappropriate advertising. They take into consideration more important characteristics and features of the food products such as quality, price, taste etc.
\end{abstract}

Keywords: food; advertising; consumer behavior; purchase; impact

\section{INTRODUCTION}

Advertising belongs to a group of marketing communication tools used to communicate with the companies as well as target consumers. Advertising can be used as a paid impersonal ability, moving from a seemingly simple task of conveying information to a lower level, potentially seeking to attract more and more sophisticated consumers (Mokrý et al., 2016).

To be effective and influence human behavior, the advertisement has to pass the process of receiving and processing (Nagyová et al., 2014). This means that the viewer must perceive and understand it by using the senses. That's why the creators of advertisements use the psychological aspects of perception and psychological tricks.

Rybanská (2015) points out the importance of psychological characteristics that need to be known because they influence individual decision making. When creating an advertisement, the lifestyle of the target group, personal attitudes, habits, etc. should be taken into account (Géci, Nagyová and Rybanská, 2017). The impact of psychology on consumers is individual, but there are also general patterns that are used in advertising because they affect their perception (Nagyová et al., 2018b).
The psychology of advertising is perceived by Andocsová, Géci and Kubelaková (2017) as an industry focused on emphasizing the merits of a product or service, which seeks to create the feeling that one needs this product urgently. The psychology of advertising addresses the recipient in an increasingly sophisticated way and seeks to motivate the recipient to buy the product.

Every human being manifests some behavior and responses to stimuli from the environment (Nagyová et al., 2019). The perception, movement and manifestation of people can be described by a simple term as human behavior. In situations where an object for consumption is attached in any way to this behavior, we are talking about consumer behavior (Kozelová et al., 2011; Kozelová, et al. 2014). According to Kádek (2018), consumer behavior is predetermined by the inclusion of a person in society and his or her behavior in general.

Koprda (2014) refers to the manipulation of consumers with the offer of companies on the market as consumer behavior. If consumers are satisfied, they can generate interest from others through positive reviews. In the case of dissatisfaction and complaints, the overall interest in the product offerings decreases. 
Consumer behavior according to Džupina, Hodinková and Kiková (2016) and Ubrežiová et al. (2019) reflects the whole of consumer decisions regarding the acquisition, consumption and disposition of goods, services, activities and experiences of human decision-making units.

Nagyová et al. (2018a) sees consumer psychology as a specialized area that explores how our thoughts, beliefs, feelings and perceptions affect how we buy goods and use services.

Experts in consumer psychology, respectively in the psychology of marketing, deal with these topics:

- the way consumers choose businesses, products and services;

- thought, processes and emotions in decision making;

- how variables such as friends, family, media and culture affect the decision;

- the reasons why consumers prefer one product over another;

- personal and individual reasons.

Advertising is a means that has a significant impact on the broader society and public opinion, gets everyone's awareness, influences our moods and behaviors, so it is essential that advertising adheres to ethical principles, and at the same time it is important that its compliance is controlled (Polakevičová, 2015).

\section{Scientific hypothesis}

For a deeper analysis of the research objectives, the following hypotheses were formulated:

Hypothesis 1: The sample is representative in terms of respondents' age.

Hypothesis 2: We assume that the perception of inappropriate food advertising is age-dependent.

Hypothesis 3: We assume that there is a link between the impact of inappropriate advertising on food and its subsequent purchase.

\section{MATERIAL AND METHODOLOGY}

The main aim of the paper was to find out how advertisements promoting food products influence consumer behavior.

As it was mentioned above, for the purposes of the questionnaire survey, hypotheses were established at the outset which, using statistical methods, can be confirmed or disproved on the basis of the survey results.

In order to ascertain the attitudes and opinions of consumers, a questionnaire survey was carried out via

Table 1 Respondents Divided by Age.

\begin{tabular}{lc}
\hline Age of respondents & Number \\
\hline Up to 25 years & 296 \\
$26-35$ & 194 \\
$36-45$ & 92 \\
$46-55$ & 72 \\
56 and more & 48 \\
TOTAL & $\mathbf{7 0 2}$ \\
\hline
\end{tabular}

Note:Source: Authors, own research.
Internet by participating of 702 respondents from the Slovak Republic (Table 1) and was conducted at Department of Marketing and Trade, FEM SUA in Nitra.

\section{Statistic analysis}

The evaluation of the questionnaire consisted of comparing the individual answers of the questions in graphical form and by using the following statistical tests (Matejková, Pietriková and Poláková, 2014):

\section{Chi-square test of good compliance}

The Chi -square of the test of compliance is calculated according to formula (1):

Where:

$$
\chi^{2}=\sum_{i=1}^{\mathrm{k}} \frac{\left(\mathrm{E}_{\mathrm{i}}-\mathrm{T}_{\mathrm{i}}\right)^{2}}{\mathrm{~T}_{\mathrm{i}}}
$$

Ei - empirical abundance,

$\mathrm{Ti}$ - theoretical abundance,

$\mathrm{r}$ - number of rows.

The critical value is expressed as: $\mathrm{x} 2(\alpha,(\mathrm{n}-1) .(\mathrm{k}-1))$. If the calculated value is greater than the critical value, the null hypothesis is rejected and an alternative hypothesis is accepted that says the sample at the selected significance level is not representative.

\section{Chi Square contingency test}

The Chi -square contingency test is calculated according to the formula (2):

$$
\chi^{2}=\sum_{i=1}^{r} \sum_{j=1}^{s} \frac{\left(\mathrm{E}_{\mathrm{ij}}-\mathrm{T}_{\mathrm{ij}}\right)^{2}}{T_{i j}}
$$

Where:

Ei - empirical abundance,

$\mathrm{Ti}$ - theoretical abundance,

$\mathrm{r}$ - number of rows,

$\mathrm{s}$ - number of columns.

The critical value is expressed as: $\mathrm{x} 2(\alpha,(\mathrm{n}-1) .(\mathrm{k}-1))$. If the calculated value is greater than the critical value, the null hypothesis is rejected and an alternative hypothesis is accepted that says there is a dependency between the nominal data examined at the selected significance level.

\section{Kolmogorov - Smirnov test}

It is used when it is necessary to compare consumer preferences with theoretical or hypothetical preferences. It is used for nominal data for one sample.

The null hypothesis, $\mathrm{H} 0$, argues that there is no difference between consumer preferences and theoretical preferences.

An alternative hypothesis, $\mathrm{H} 1$ argues that there is a difference between consumer preferences and theoretical preferences.

The test characteristic is calculated using the formula (3):

Where:

$$
\text { Dcal. }=\max [\text { abs }(\mathrm{Fi}-\mathrm{Gi})]
$$

Dcal. - calculated test characteristic,

$\mathrm{Fi}$ - cumulative relative abundance,

$\mathrm{Gi}$ - cumulative theoretical abundance.

The tabular value is calculated using the formula (4):

$$
\frac{1,36}{\sqrt{n}} \text { for } \alpha=0.05
$$

Where:

$\mathrm{n}$ - number of respondents,

$\alpha$-significance level. 


\section{RESULTS AND DISCUSSION}

Consumer behavior is one of the constantly evolving and changing elements of today's world (Carlucci et al., 2015). To understand it, it is necessary to examine the complex interaction of many influencing elements (Moutinho, 1987), e.g. the impact of advertising as it was examined e.g. by Story and French (2004), Lobstein and Dibb (2005), Chou et al. (2008), Harris et al. (2009), Kelly et al. (2010), Andreyeva et al. (2011), Vukmirovic (2015) etc. who's attention was mainly focused on children and the impact of the advertising on them.

Braun et al. (2002), Hupp et al. (2008), Lichtlé et al. (2014), Šugrová et al. (2017), Nagyová et al. (2018a) and Ubrežiová et al. (2019) proved that advertising can lead to strong emotional arousal, marketers can use this method to engage with consumers regardless of the product they are promoting.

Another studies by different authors (Horská and Orémus, 2008; Rybanská, 2015; Berčík et al. 2016; Andocsová, Géci and Kubelaková, 2017) pointed out that, emotional branding strategy is a common advertising technique that many popular company's use to engage with consumers on a more personal level.

Respondents involved in a survey had been asked to answer questions related to their attitude to inappropriate food advertising and personal experience with such kind of advertising influencing their purchasing behavior. As seen in Table 1, we have analysed answers by total 702 respondents from the Slovak Republic (41\% of respondnets were up to 25 years, $28 \%$ of respondnets between 26 and 35 years, 13\% between 36 and 45 years, $10 \%$ between 46 and 55 years and 8\% were 56 years and older).

\section{In your opinion, what food advertising is inappropriate?}

In the aswers on the above-mentioned question were listed several characteristics of the ad, that may be a reason for the inappropriate nature, while respondents were invited to indicate more options.

Under term "Inappropriate food advertising", most consumers imagine advertising that is deceptive (98\%) and misleading (78\%). The respondents made their decision mainly based on their own emotions (Figure 1).

Besides that, the current situation on the food market is influenced by various diet trends including eating healthy products (Guziy, Šedík and Horská, 2017).

\section{Do you have personal experience with an} inappropriate food advertising?

Respondents consider as inappropriate or unethical advertisements presenting yogurts with plenty of fruit, while the reality is different. Also unethical are

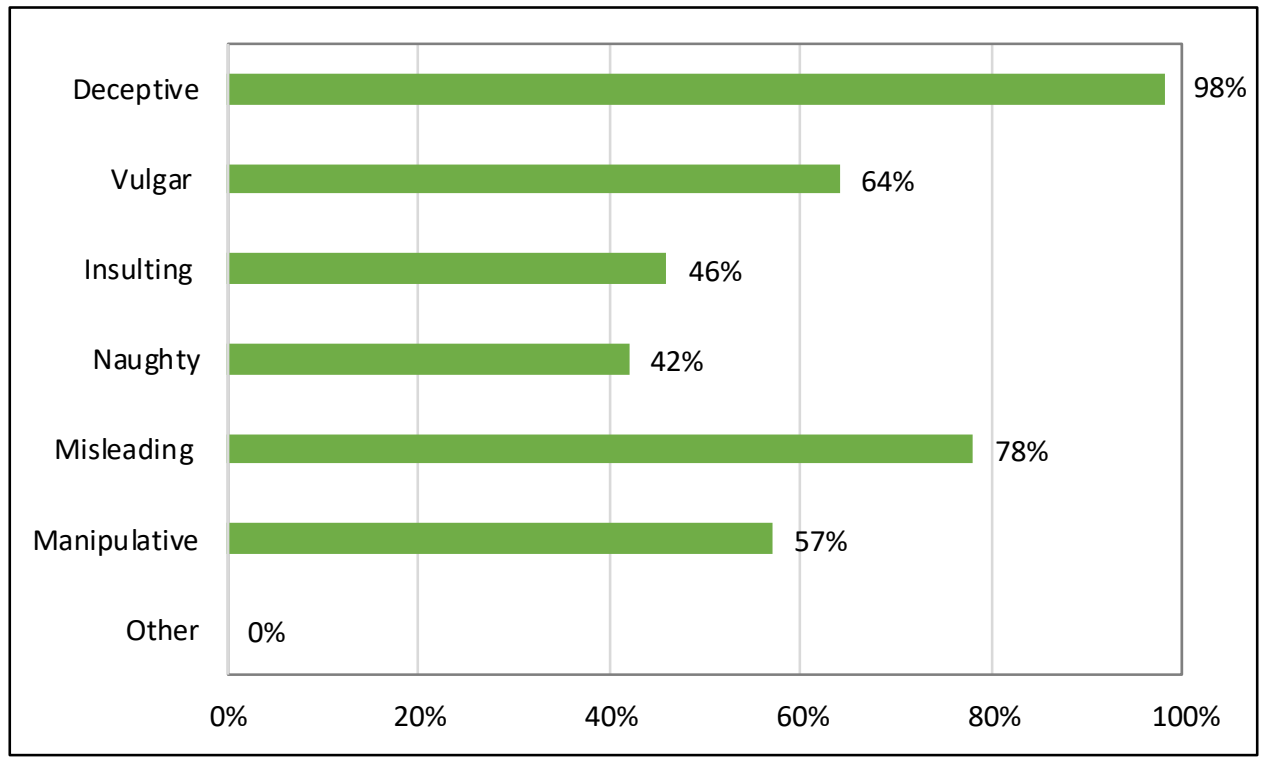

Figure 1 Characteristics of Inappropriate Food Advertising. Note: Source: Authors, own research.

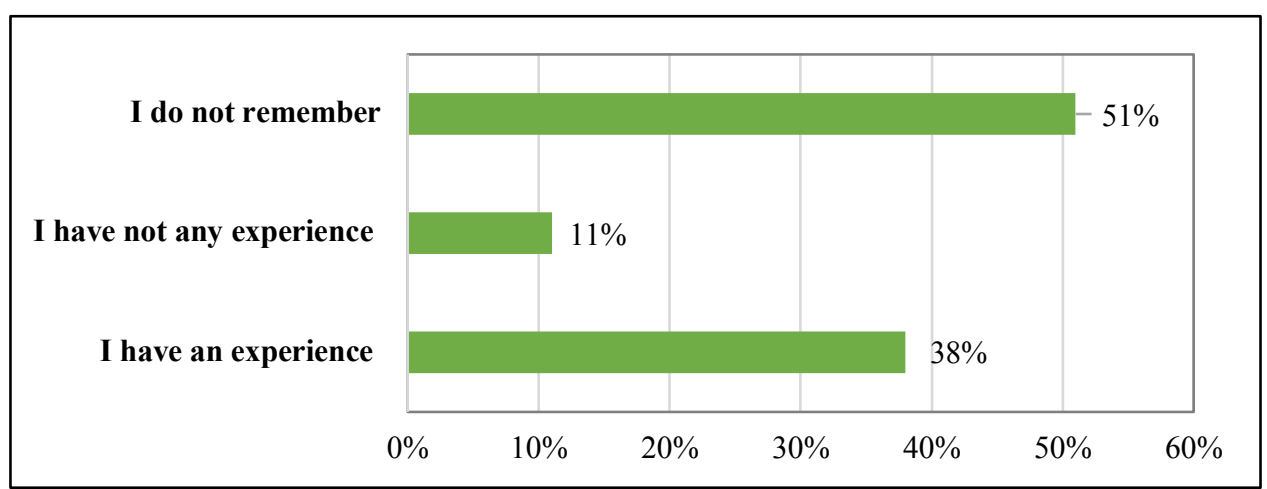

Figure 2 Personal Experience with an Inappropriate Food Advertising. Note: Source: Authors, own research. 
Table 2 Results of Chi-square, Chi-square Contingency Test and Kolmogorov-Smirnov Test.

\begin{tabular}{cccccccc}
\hline & Chi-square Test & \multicolumn{3}{c}{ Chi-square Contingency Test } & \multicolumn{3}{c}{ Kolmogorov-Smirnov test } \\
TCH & & TH & TCH & & TH & TCH & TH \\
\hline 0.81 & $<$ & 9.47 & 15.507 & $>$ & 0.49 & 0.11 & $>$ \\
\hline
\end{tabular}

Note: Source: Authors, own research.

Table 3 Results of Kolmogorov - Smirnov test.

\begin{tabular}{|c|c|c|c|c|c|c|}
\hline Attitude & $\begin{array}{c}\text { Absolute } \\
\text { abundance }\end{array}$ & $\begin{array}{c}\text { Relative } \\
\text { abundance }\end{array}$ & $\begin{array}{c}\text { Cumulative } \\
\text { relative } \\
\text { abundance }\end{array}$ & $\begin{array}{l}\text { Theoretical } \\
\text { abundance }\end{array}$ & $\begin{array}{l}\text { Cumulative } \\
\text { theoretical } \\
\text { abundance }\end{array}$ & $\begin{array}{c}\text { abs } \\
\left(F_{\mathrm{i}}-\mathbf{G}_{\mathbf{i}}\right)\end{array}$ \\
\hline positive & 148.00 & 0.21 & 0.22 & 0.33 & 0.33 & 0.11 \\
\hline negative & 253.00 & 0.36 & 0.57 & 0.34 & 0.67 & 0.10 \\
\hline neutral & 301.00 & 0.43 & 1.00 & 0.33 & 1.00 & 0.00 \\
\hline Total & 702.00 & 1.00 & & & & \\
\hline
\end{tabular}

Note: Source: Authors, own research.

advertisements for nutritional supplements, e.g. for building the muscles without working out. Consumers also feel deceived when presenting healthy sticks and also butter, although the reality is different. $38 \%$ of respondents have the personal experience with an inappropriate advertising, while only $11 \%$ of respondents have not encountered such advertising. Up to $51 \%$ of respondents admit personal experience with the inappropriate food advertising, but they exactly do not remember (Figure 2). Anyway, it has to be stated that advertising has a strong influence and impact on consumer behavior even in the $21 .{ }^{\text {st }}$ century (Vivek, Beatty and Morgan, 2014; Nagyová et al., 2014).

\section{Statistical hypothesis testing}

\section{Hypothesis 1}

H0: The sample is representative in terms of respondents' age.

H1: The sample is not representative in terms of respondents' age.

Based on value $0.81<9.47$, we accept the hypothesis $\mathrm{H} 0$. With $95 \%$ probability can be said, that the sample is representative in terms of respondent age (Table 2).

Hypothesis 2

H0: We assume that the perception of inappropriate food advertising is age-dependent.

$\mathrm{H} 1$ : We assume that the perception of inappropriate food advertising is not age-dependent.

Based on a value $15.507>0.49$ can be concluded that we reject the hypothesis $\mathrm{H} 0$ and accept the hypothesis $\mathrm{H} 1$. With $95 \%$ probability can be said that the perception of inappropriate food advertising is not dependent on the respondent's age (Table 2).

According the research by APA (2019), there is proven association between advertising and age of respondents but mainly in most children under age 6 , who cannot distinguish between programming and advertising and children under age 8 who do not understand the persuasive intent of advertising. Advertising directed at children this young is by its very nature exploitative. Children have a remarkable ability to recall content from the ads to which they have been exposed. Product preferences affect children's product purchase requests and these requests influence parents' purchasing decisions.

\section{Hypothesis 3}

H0: We assume that there is a link between the impact of inappropriate food advertising and its subsequent purchase. H1: We assume that there is not a link between the impact of inappropriate food advertising and its subsequent purchase.

On the basis of the value $0.11>0.10$ we reject the hypothesis $\mathrm{H} 0$ and accept the hypothesis $\mathrm{H} 1$, which means that the relationship of the influence of inappropriate advertising on food on their subsequent purchase was not statistically proven (Table 3 and Table 2). Research by Nagyová et al. (2014), Rybanská (2015) and Šugrová et al. (2017) also proved, that the advertising has only lower impact on consumer behavior, as the most important factors in condition of the Slovak Republic, influencing the consumers buying behavior are price, quality, taste, reliable references etc.

\section{CONCLUSION}

Our research was aimed at the impact of inappropriate advertising on consumer behavior when purchasing the food previously seen in advertisement. Results of the research conducted at FEM SUA in Nitra are on the basis of a questionnaire survey with a sample of 702 respondents from the Slovak Republic. It has been proven that $38 \%$ of respondents have a personal experience with inappropriate food advertising and most respondents considered inappropriate food advertising as a deceptive, misleading and manipulative one. We have tested three hypothesis:

H1: The sample is representative in terms of respondents' age. 
$\mathrm{H} 2$ : We assume that the perception of inappropriate food advertising is age-dependent.

H3: We assume that there is a link between the impact of inappropriate advertising on food and its subsequent purchase.

We have obtained following results:

The research sample is representative in terms of respondent age (Hypothesis 1 was accepted).

Perception of inappropriate food advertising is not dependent on the respondent's age (Hypothesis 2 was rejected).

And the relationship of the influence of inappropriate advertising on food on their subsequent purchase was not statistically proven (Hypothesis 3 was rejected).

On the basis of above stated results can be concluded that respondents are not influenced by inappropriate food advertising when buying food previously seen in advertisement. They take into consideration more important characteristics and features of the food products such as quality, price, taste, reliable references etc.

\section{REFERENCES}

Andocsová, A., Géci, A., Kubelaková, A. 2017. The Impact of Online Marketing of Selected Retail Stores on Consumer's Behaviour of the Young Generation. In Proceeding from the conference: Marketing Identity, Trnava, Slovakia : University of st. Cyril and Methodius in Trnava. p. 116-125.

Andreyeva, T., Kelly, I. R., Harris, J. L. 2011. Exposure to food advertising on television: Associations with children's fast food and soft drink consumption and obesity. Economics \& Human Biology, vol. 9, iss. 3, p. 221-233. https://doi.org/10.1016/j.ehb.2011.02.004

APA. 2019. The impact of food advertising on childhood obesity. Available at: https://www.apa.org/topics/kids-media/

Berčík, J., Palúchová, J., Vietoris, V., Horská, E. 2016. Placing of aroma compounds by food sales promotion in chosen services business. Potravinarstvo, vol. 10, no. 1, p. 672679. https://doi.org/10.5219/666

Braun, K. A., Ellis, R., Loftus, E. F. 2002. Make my memory: How advertising can change our memories of the past. Psychology \& Marketing, vol. 19, iss. 1, p. 1-23. https://doi.org/10.1002/mar.1000

Carlucci, D., Nocella, G., De Devitiis, B., Viscecchia, R., Bimbo, F., Nardone, G. 2015. Consumer purchasing behaviour towards fish and seafood products. Patterns and insights from a sample of international studies. Appetite, vol. 84, p. 212-227. https://doi.org/10.1016/j.appet.2014.10.008

Chou, S-Y., Rashad, I., Grossman, M. 2008. Fast-Food Restaurant Advertising on Televisio and Its Influence on Childhood Obesity. The Journal of Law and Economics, vol. 51, no. 4, p. 599-618. https://doi.org/10.1086/590132

Džupina, M., Hodinková D., Kiková, H. 2016. Spoločensky zodpovedné podnikanie ako zdroj hodnoty značky (Corporate social responsibility as a source of brand value). Nitra : UKF. p. 84. (In Slovak).

Géci, A., Nagyová, L', Rybanská, J. 2017. Impact of sensory marketing on consumer's buying behavior. Potravinarstvo Slovak Journal of Food Sciences, vol. 11, no. 1, p. 709-717. https://doi.org/10.5219/835

Guziy, S., Šedík, P., Horská, E. 2017. Comparative study of honey consumption in Slovakia and Russia. Potravinarstvo Slovak Journal of Food Sciences, vol. 11, no. 1, p. 472-479. https://doi.org/10.5219/784
Harris, J. L., Bargh, J. A:, Kelly, D. 2009. Priming effects of television food advertising on eating behaviour. Health Psychology, vol. 28, no. 4, p. 404-413.

Horská, E., Orémus, P. 2008. Processes and problems of the marketing management adaptation at the EU market: The case of the Slovak meat processing industry. Agricultural economics, vol. 54, p. 392-398. https://doi.org/10.17221/295AGRICECON

Hupp, O., Groppel-Klein, A., Dieckmann, P., Walter, K. 2008. Yearbook of Marketing and Consumer Research, vol. 6 , p. 72-99.

Kádek, P. 2018. Právna zodpovednost' $v$ medicíne a zdravotnictve. (Legal responsibility in medicine and healthcare). 2nd edition. Bratislava : Wolters Kluwer SR. p. 222. ISBN 978-80-8168-651-1. (In Slovak)

Kelly, B. et al. 2010. Television Food Advertising to Children: A Global Perspective. American Journal of Public Health 100, no. 9, p. 1730-1736. https://doi.org/10.2105/AJPH.2009.179267

Koprda, T. 2014. Teoretické konštrukty spotrebitel'ského správania $\mathrm{v}$ marketingovej komunikácii. (Theoretical constructions of consumer behavior in marketing communication). In Proceeding from the conference: Nové výzvy masmediálnej a marketingovej komunikácie IV (New challenges of mass media and marketing communication IV) : recenzovaný zbornik príspevkov zo 4. ročníka vedeckoodborného seminára. Nitra, Slovakia : UKF. p. 5-11. (In Slovak)

Kozelová, D., Matejková, E., Fikselová, M., Dékányová, J. 2014. Analysis of consumer behavior at chocolate purchase. Potravinarstvo, vol. 8, no. 1, p. 62-66. https://doi.org/10.5219/325

Kozelová, D., Mura, L., Matejková, E., Lopašovský, L., Vietoris, V., Mendelová, A., Bezáková, M., Chreneková, M. 2011. Organic products, consumer behavior on market and european organic product market situation. Potravinarstvo, vol. 5, no. 3, p. 20-26. https://doi.org/10.5219/96

Lichtlé, M.-Ch., Plichon, V. 2014. les émotions ressenties dans un point de vente : Proposition d'une echelle de mesure. Recherche et Applications en Marketing (RAM), vol. 29, iss. 1, p. 3-26. https://doi.org/10.1177/0767370113505952

Lobstein, T., Dibb, S. 2005. Evidence of a possible link between obesogenic food advertising and child everweight. Obesity Reviews, vol. 6, iss. 3, p. 203-208. https://doi.org/10.1111/j.1467-789X.2005.00191.x

Matejková, E., Pietriková, M., Poláková, Z. 2014. Praktikum zo štatistiky A. (Practice in Statistics A). Nitra, Slovakia : SPU. 199 p. ISBN 978-80-552-1050-6. (In Slovak).

Mokrý, S., Birčiaková, N., Slováčková, T., Stávková, J., Nagyová, L'. 2016. Perception of wine labels by generation Z: eye-tracking experiment. Potravinarstvo, vol. 10, no. 1, p. 524531. https://doi.org/10.5219/647

Moutinho, L. 1987. Consumer Behaviour in Tourism, European Journal of Marketing, vol. 21, no. 10, p. 544. https://doi.org/10.1108/EUM0000000004718

Nagyová, L., Horská, E., Kubicová, L., Turčínková, J., Vaňová, A., Neomániová, K., Košičiarová, I., Kádeková, Z., Souček, M., Berčík, J., Holienčinová, M., Rybanská, J. 2014. Marketingová komunikácia. (Marketing Communication) Nitra, Slovakia : SUA. 381 p. ISBN 978-80-552-1270-8 (In Slovak).

Nagyová, L'., Holienčinová, M., Kádeková, Z., Košičiarová, I., Récky, R., Stávková, J., Šugrová, M. 2018a. Marketing I. Nitra : SUA. 253 p. ISBN 978-80-552-1840-3 (In Slovak).

Nagyová, L', Berčík, J., Džupina, M., Hazuchová, N., Holienčinová, M., Kádeková, Z., Koprda, T., Košičiarová, I., 
Récky, R., Rybanská, J. 2018b. Marketing II. Nitra : SUA. 453 p. ISBN 978-80-552-1943-1. (In Slovak).

Nagyová, L., Andocsová, A., Géci, A., Zajác, P., Palkovič, J., Košičiarová, I., Golian, J. 2019. Consumers' awareness of food safety. Potravinarstvo Slovak Journal of Food Sciences, vol. 13, no. 1, p. 8-17. https://doi.org/10.5219/1003

Polakevičová, I. 2015. Aplikácia transakčnej analýzy do oblasti marketingovej komunikácie. (Application of transactional analysis into the field of marketing communication). Nitra : UKF. 192 p. (In Slovak) ISBN 97880-558-0892-5.

Rybanská, J. 2015. Selected personality characteristics as predictors of emotional consumer behaviour. European Journal of Business Science and Technology, vol. 1, no. 2, p. 128-136. https://doi.org/10.11118/ejobsat.v1i2.26

Story, M., French, S. 2004. Food Advertising and Marketing Directed at Children and Adolescents in th US. International Journal of Behavioral Nutrition and Physical Activity, https://doi.org/10.1186/1479-5868-1-3

Šugrová, M., Šedík, P., Kubelaková, A., Svetlíková, V. 2017. Customer satisfaction: The impact of products quality and services on the brand and corporate image. Economics, management, finanace and social attributes of ekonomic system (EMFSA 2017). 1. ed. EMFSA 2017. Považská Bystrica : BCSS L.L.C., 71 p.

Ubrežiová, I., Urbánová, M., Kozáková, J., Králová, T. 2019. Gender defferences in consumer preferences when buying dairy products in Slovakia and Russia. Potravinarstvo Slovak Journal of Food Sciences, vol. 13, no. 1, p. 720-729. https://doi.org/10.5219/1157

Vivek, D. S., Beatty, E. S., Morgan, M. R. 2014. Customer Engagement: Exploring Customer Relationships Beyond Purchase. Journal of Marketing Theory and Practice, vol. 20, no. 2, p. 122-146. https://doi.org/10.2753/MTP1069$\underline{6679200201}$

Vukmirovic, M. 2015. The effects of food advertising on food-related behaviours and perceptions in adults: A review. Food Research International, vol. 75, p. 13-19. https://doi.org/10.1016/j.foodres.2015.05.011

\section{Acknowledgments:}

The paper was supported by the research project VEGA $1 / 0502 / 17$ "The personality of the consumer and his impact on emotional behavior and consumer judgment".

\section{Contact address:}

*Ing. Zdenka Kádeková, PhD., Slovak University of Agriculture in Nitra, Faculty of Economics and Management, Department of Marketing and Trade, Trieda A. Hlinku 2, 94976 Nitra, Slovakia, Tel.: +42137 641 4171, E-mail: zdenka_kadekova@yahoo.com

ORCID: https://orcid.org/0000-0003-2814-5239

Ing. Ingrida Košičiarová, PhD., Slovak University of Agriculture in Nitra, Faculty of Economics and Management, Department of Marketing and Trade, Trieda A. Hlinku 2, 94976 Nitra, Slovakia, Tel.: +42137 641 4171, E-mail: ingrida.kosiciarova@gmail.com

ORCID: https://orcid.org/0000-0003-3763-0826

Ing. Mária Holotová, PhD. Slovak University of Agriculture in Nitra, Faculty of Economics and Management, Department of Accountancy, Trieda A. Hlinku 2, 94976 Nitra, Slovakia, Tel.: +42137 641 4171,

E-mail: maria.holotova@uniag.sk

ORCID: https://orcid.org/0000-0002-2350-1284

doc. Ing. L'ubica Kubicová, PhD., Slovak University of Agriculture in Nitra, Faculty of Economics and Management, Department of Marketing and Trade, Trieda A. Hlinku 2, 94976 Nitra, Slovakia, Tel.: +42137 641 4165, E-mail: kubicova.lubka@gmail.com

ORCID: https://orcid.org/0000-0003-3789-6894

Ing. Kristína Predanocyová, Slovak University of Agriculture in Nitra, Faculty of Economics and Management, Department of Marketing and Trade, Trieda A. Hlinku 2, 94976 Nitra, Slovakia, Tel.: +42137 641 4835, E-mail: kristina.predanocyova@gmail.com ORCID: https://orcid.org/0000-0001-8867-1666

Corresponding author: * 